\title{
Political Change in Tahiti and Samoa: An Exercise in Experimental Anthropology ${ }^{1}$
}

\author{
F. Allan Hanson \\ University of Kansas
}

The experimental method is often taken to be a private domain of natural science. Indeed, many hold it to be responsible for the fabled progress and exactitude of the natural sciences as contrasted with the more intuitive approach and pedestrian advance of a discipline like social anthropology. Yet the thesis of this paper is that the experimental method is by no means a monopoly of natural science. I shall attempt to demonstrate that it can be used effectively to solve certain problems in social sciece as well.

The vehicle for the demonstration is a problem in Polynesian ethnology. Two distinct hypotheses are available as candiadtes for explaining the problem. As in the natural sciences, we shall evaluate the hypotheses by the experimental method. It is possible to subject them to a "crucial test"-crucial in the sense that by corroborating one hypothesis the experiment falsifies the other (Hempel 1966: 25-26). In fact, two such experiments can be devised, one relying on historical materials and the other using the method of controlled comparison (Eggan 1954). Hopefully these tests will demonstrate that Polynesia is indeed, as Keesing (1947: 39) and Mead (1957) have termed it, a human laboratory.

\section{The Problem}

Polynesian cultures have developed quite differently in the post-European period. Beaglehole (1957: 237-238) has said:

If one thinks primarily of Tahiti, the Marquesas and Hawaii one may be forced to think of social change as characteristic of Polynesia. If, on the contrary, one thinks of the Cook Islands, Tonga, Samoa and even New Zealand it is resistance to change and a strain of conservatism that strikes one most forcibly.

There could be no clearer example of this distinction than the differing fates of indigenous political organization in Tahiti and Samoa. Government in modern Tahiti bears no vestige of the highly stratified ancient system whereby rank and the right to rule were determined by noble ancestry and primogeniture. Instead one finds a French-inspired system of councils and assemblies elected by universal suffrage and colonial administrators appointed from Paris (West 196r: 66-99). But the Samoans, 


\section{Ethnology}

"the most conservative of Polynesians" (Keesing 1937: 14), have retained almost intact their local political system based on elected family title-holders and village and district councils (West 196r: 136; Beaglehole r948: 63; Keesing 1934a: 47-52; Stanner 1953: 314-315). The problem which arises immediately, and for which I hope to construct a solution utilizing the experimental method, is: why has political organization changed so much in Tahiti and so little in Samoa?

One comment before proceeding: different Polynesianists would not treat our problem in the same way. Those primarily interested in Samoa tend to ask "why did Samoa change so little?" while for those mainly concerned with Tahiti the question resolves into "why did Tahiti change so much?" As I am primarily a student of eastern Polynesia, the reader should not be surprised to find more in these pages about Tahiti than about Samoa.

\section{Hypothesis I : Conversion to Christianity}

Religion was of quite different significance in the pre-European cultures of Tahiti and Samoa. The first hypothesis holds that for this reason conversion to Christianity had a different impact on the two societies, and that this explains the different degrees of political change.

Religion was the keystone of ancient Tahitian society. At the beginning of the nineteenth century, just prior to conversion, Tahiti was divided into fifteen or twenty semi-autonomous districts. Political power over these districts and their subdivisions was vested in titles, which were held in ranking families and inherited by a strict rule of primogeniture. Each district and subdistrict had a marae-an open courtyard where religious ceremonies were held. Within the courtyard were several upright stone slabs, which served as backrests against which title-holders sat during religious rites. Each of these stones was associated with a particular title. A titleholder validated his right to his title, and to the lands and political prerogatives it conveyed, by sitting at the spot associated with it in the marae. The whole idea of political authority in old Tahiti rested on a divine sanction as symbolized by the marae. Hence Ari'i Taimai (Adams I90r: 15), calls the marae "the record of rank and title throughout the island," Tati Salmon (Igro: 43), terms it the title deed of rank and Henry (r928: I4I) adds: "to the marae were attached the hereditary names of the family, without which they could give no proof of their ownership of land." Add to this the facts that the symbols of extreme rank, such as the red and yellow feather girdles, were religious paraphernalia and that political alliances were often grounded in the fact that the allies were followers of the same god (Newbury 1967b: 479-480), and it is clear that in Tahiti religion was the validation of political organization.

The role of religion in aboriginal Samoa was, by comparison with Tahiti, greatly truncated. "In religious development." says (Mead I928: 494), "Hawaii, Tahiti, New Zealand and the Marquesas all out-distance Samoa in richness and variety of religious forms and beliefs and in the relative importance of religion in the lives of the people." Local government in Samoa 
was largely a matter of titles which were associated with family groups and ranked relative to each other. Title-holders were elected by their family groups and represented them in the village council (fono). In this governing body of the village, each member's influence depended largely on the rank of his title. Certain members of the village council represented the village in councils at higher levels-the subdistrict, district, district alliance, etc. (Keesing 1934a: 48-52).

This political system of titles and councils was largely independent of religion. As an old chief put it to Margaret Mead: "the people of old had two great gods, Tagaloa and the village, and the village was the greater of the two" (quoted in Stanner 1953: 317). It is symbolic of the elevation of politics over religion in Samoa that the malae (cognate of the Tahitian marae) was not a sacred structure but a village green where important political affairs were held (Keesing 1934a: 49, 399). Indeed, what links existed between political and religious organization in Samoa indicate the dependence of religion upon politics, rather than vice versa as was characteristic of Tahiti (Keesing 1934a: 399-400). Thus, after conversion, Samoan custom seems to have changed Christianity more than it was changed by it. As a missionary told Stanner (1953: 292):

Instead of accepting Christianity and allowing it to remould their lives to its form, the Samoans have taken the religious practices taught to them and fitted them inside Samoan custom, making them a part of the native culture. ... Christianity, instead of bursting the bond of the old life, has been eaten up by it!

With this background we may now state formally the first hypothesis. In pre-European times political organization was dependent upon religion in Tahiti but not in Samoa. Therefore conversion to Christianity undermined the Tahitian political system, leaving it easy prey for any force which might be raised up against it, while conversion had no weakening effect upon political organization in Samoa. Hence political organization in Tahiti crumbled, whereas in Samoa it has adhered far more closely to the traditional form.

To my knowledge the first to enunciate this hypothesis were the missionaries John Davies and John Williams. Davies (I96r: 328) wrote: "the case of the Tahitians was such that without the overthrow of their religious system they could not change their customs, or in other words adopt the modes and manners of civilized life, because their Religion was so blended with everything they did, all their employments, customs, diversions and affairs of Government." Williams (I837: 126) spoke of the Tahitians and Cook Islanders in a similar vein: "as their civil polity was intimately interwoven with their sanguinary idolatry, when one was subverted the other perished in its ruins, whilst the ancient usages, which were in accordance with the spirit of their religion, of necessity sank into decay, when the people were brought under the mild influence of Gospel principles."

This hypothesis has also been advanced from a Samoan point of view. After pointing out how religion was subsidiary to political organization in Samoan culture, Keesing (1934a: 400) wrote: 


\section{Ethnology}

This circumstance was very significanct for the future story of Samoa. Where, in other areas, notably Hawaii, the crumbling of the religious system shook to its fous dations the existing social organization and prepared the way for sweeping change in the whole cultural setting of native life, in Samoa the chiefs and orators merel rejected one set of interpretations and functions and took over the other without ant vital blow being struck at the fundamentals of the existing order. ${ }^{2}$

And Mander (1954: 83) stated: "the political and social life [of Somaay were not dominated by the religion, with the result that the introduction of Christianity did not cause so serious a crisis in social institutions a elsewhere in the Pacific."

Hence we see that the first hypothesis has been around for a long time and has been espoused by rather diverse people. It is certainly plausible an appealing, perhaps especially so to those of a functional bent, who an attuned to relations of reinforcement and interdependence among socia usages and institutions. Our problem, however, is susceptible to an $a^{j}$ ternative explanation.

\section{Hrpothesis 2: The Colonial Experrence}

The second hypothesis relates to historical developments of the poa European period. Tahiti and Samoa had quite different experiences at the hands of colonial powers, and this difference may account for the different degrees of political change in the two areas.

Tahiti's colonial masters were (and are) the French. This association has endured for well over a century, beginning with the establishment of a French Protectorate in 1842 . While the protectorate treaty called for in ternal affairs to be left in native hands, in fact the French moved early in an effort to transform Tahitian society. They practiced a colonial policy known as direct rule, where the goal is to assimilate natives into the metro politan society. In theory it is a benevolent (if ethnocentric) policy which aims to make fully available to the Tahitians and other colonized peoples the benefits and rewards of French citizenship and French civilization. In implementing such a policy it was of course necessary that native social and political institutions be replaced with their French counterparts. At West (196r: 99 ) has stated:

Assimilation in practice has meant that in Tahiti the institutions through which political advancement can occur are distinctively French. . . . From the early staga of colonial government the French have ignored traditional institutions; certainly they have not attempted to use the old system of rank and authority, and where they. have preserved something of a formal position, like a district chief, the office has in fact been a modern administrative one and not at all traditional. The loi-cadre repre sents administrative assimilation to the metropolitan French institutions which have been provided for the whole of the Union or Community, with the corollaries that the society within which these institutions exist is dominated by French values, French education and French culture. Plainly it assumes that Tahitians are French ... thr political advancement shall be distinctively French and not Polynesian.

Samoa's colonial experience was very different. First of all, Samoa dic not come under formal colonial control until 1900, far later than was the case in Tahiti. This was not because of lack of interest on the part of the 
metropolitan powers, but quite the opposite. No fewer than three nationsGermany, Great Britain, and the United States-claimed interests in Samoa, and the main reason that Samoa was not made a colony earlier was that none of these powers was willing to allow such an advantage to the others (Masterman 1934: 150-198).

Again unlike Tahiti, when Samoa finally did become a colony it was not subjected to a policy of assimilation. In 1900 Western Samoa came under German control while Eastern Samoa was taken by' the United States. (Great Britain relinquished her claims in return for colonial concessions elsewhere.) Upon the outbreak of World War I, Western Samoa was taken from Germany by New Zealand. All three of the nations which have exercised colonial powers in Samoa followed a policy of indirect rather than direct rule. That is, rather than attempting to replace indigenous institutions and values with their metropolitan counterparts, these nations retained Samoan institutions and customs and ruled through them. To be sure, some changes were made at the highest levels of island government in order to transform what had been alternating periods of open conflict and uneasy truce between rival factions into a stable administration subject to metropolitan control. But Germans, Americans, and New Zealanders alike maintained at the local and district levels the traditional Samoan system of village councils (fono) peopled by representatives (matai) elected from family groups (Keesing r934b; Lowe and Airey r945).

Hence our second hypothesis: political organization has changed far more in Tahiti than in Samoa because the French colonial policy of direct rule and assimilation transformed Tahitian society out of all recognition, while the long period of Samoan independence throughout the nineteenth century, followed by German, American, and New Zealand colonial policies of indirect rule, allowed the traditional Samoan political system to function at the local levels essentially undisturbed by foreign influence. Like the first hypothesis, this one also has a number of adherents, including Beaglehole (1948:63,67-69), Stanner (1953: 316 ), West (196r: 73), and even the eclectic Keesing (r934a: 74-75), who was quoted above in support of the first hypothesis. Keesing's position demonstrates that our two hypotheses are not necessarily mutually exclusive. Yet it does seem possible to devise experimental tests which enable us to choose between them.

Test I: Rarotonga

The "human laboratory" aspect of Polynesia lends itself admirably to the task of choosing between our two hypotheses. The multiplicity of islands yields fertile ground for Eggan's method of controlled comparison (1954), for in Polynesia any number of ecological, customary, or historical variations can be isolated and analyzed against the common backdrop of a broadly similar Polynesian culture. For the problem at hand, the island of Rarotonga, in the Cook group southwest of Tahiti, occupies a fascinating and instructive position midway between Tahiti and Samoa.

Pre-European social and political organization in Rarotonga were very similar to the Tahitian. As Beaglehole (I957: II) put it: "just as the people 


\section{Etrinoloct}

in their physical makeup appear to be connected more closely with the people of the Society Islands [including Tahiti] than with any other Poly. nesian group, so Cook Island cultural emphases follow the central Poly nesian pattern." Crocombe (1964: 8-15, 25-37) describes a pre-Europeal system for Rarotonga based on districts and subdistricts, each with it herediatary chief succeeding in the male line by primogeniture, and it marae where religious ceremonies were conducted and where the high chiefs had their special seats. This is essentially the same organization a described earlier for Tahiti, so we can readily endorse Crocombe's (1964: 25) conclusion that these aspects of Rarotongan society stemmed from a Tahitian prototype.

In common with both Tahiti and Samoa, Rarotonga was converted to Christianity by the London Missionary Society. Missionaries began wont on the island in 1823 and had essentially eradicated heathenism by thi early 1830s (Buzacott 1866: 30-56).

While Rarotonga's traditional culture resembled the Tahitian, its es: perience with colonialism was far more similar to Samoa's. As in Samoa formal colonial control came late to Rarotonga. Foreign missionarie traders, and whalers were active there as early as the 1820 and 1830 , but i was not until 1888 that the British established a protectorate over the island This was replaced in 1900 by annexation to New Zealand (Beaglehole 1957 ror, Iro-r14). Again like Samoa, the British and New Zealanders tended to follow a colonial policy of indirect rule in Rarotonga, governing through existing native institutions (Crocombe 1964: 100-128).

Now consider the relevance of Rarotonga to our hypotheses concerning political change in Tahiti and Samoa. In effect, Rarotonga represents an experiment, the results of which indicate a clear choice between the hypotheses. The first hypothesis is that Tahiti changed more than Samoa bocause, with the far closer links between religion and political organization in Tahiti, conversion to Christianity seriously undermined the Tahitian political system. If this hypothesis were true, we would expect Rarotongan political organization also to have changed drastically after conversion to Christianity, because all evidence suggests that traditional Rarotongan roligious and political organization were very much on the Tahitian model.

The second hypothesis is that Tahiti changed more than Samoa because of the French colonial policy of assimilation in Tahiti as opposed to the relatively long period of independence followed by colonial policies of indirect rule in Samoa. If this hypothesis were true, we would expect Rarotongan political organization to have changed relatively little, because colonial history there resembles the Samoan experience far more than the Tahitian.

Hence Rarotongan history is a crucial test of our hypotheses, in that each hypothesis predicts (or retrodicts) different developments. Examining the facts, we find that Rarotongan political organization changed relatively little. "Looking back at a century and more of culture contact in Rarotonga ... one's abiding impression must remain an impression of cultural tenacity and stubborn conservatism rather than one of pronounced 
and lasting change" (Beaglehole 1957: 237). In fact, far from finding conversion being followed by a breakdown of political organization and chiefly power, we discover that the powers of the Rarotongan chiefs actually increased during the three-quarters of a century following conversion (Crocombe 1964: 63-94). ${ }^{8}$

The first test, then, clearly corroborates the second hypothesis concerning colonial rule and refutes the first hypothesis relating to the effects of conversion.

\section{Test 2: Tahitian History}

Our two candidates for the cause of Tahitian political change are conversion to Christianity and French colonial rule. These did not occur simultaneously, and therefore a little attention to chronology should assist us in choosing between them.

Conversion to Christianity in Tahiti occurred around 1815, whereas French colonialism did not begin until the establishment of a protectorate in 1842. Now if the cause of political change was in fact conversion, we could expect to see at least some signs of breakdown in the political system between I815 and 1842-after conversion but before the beginning of French colonialism. But if French colonial rule was responsible for the change, then we could not expect to detect weakening in the traditional political system until after I842. Moreover, a closer look at the actual historical events associated with the change should reveal whether those events were linked to conversion or to colonialism.

Although missionaries of the London Missionary Society had labored in Tahiti since I797, they made no visible progress until about I8I2. In that year Pomare II, one of the principal chiefs of Tahiti and a major figure in the rivalries and warfare dominating the period, first expressed his devotion to Jehovah (Gunson 1962: 210). In 1815 Pomare defeated the major pagan chiefs of Tahiti in the Battle of Puna'auia. Pomare II emerged from this battle as the strongest chief in Tahiti, and he moved immediately to consolidate his position as the supreme ruler over the entire island. It was the first time that any chief had been successful in achieving this goal of centralization.

Among Pomare's first acts in power were to proclaim Christianity the sole and official religion of Tahiti and to order the destruction of the pagan idols and the marae. Given the pivotal position of the marae in Tahitian culture, as described above, this latter move certainly had the potential to undercut severely the position of the chiefs and the entire political system. Indeed, that is precisely what our first hypothesis holds did happen.

The historical fact, however, is otherwise. Pomare II was anxious to concentrate supreme power in his own hands, but not to revolutionize the entire political system. "The period before the coming of the French was as much an effort to keep old forms as to accomodate the new Atua [god] which had replaced 'Oro and the old gods" (Newbury 1967a: 14; see also Newbury 1967b: 498-499). Thus Pomare retained intact the traditional political organization of districts and subdistricts ruled by title-holders of 


\section{Ethnology}

high rank who succeeded by primogeniture. Beyond rewarding a few staunch allies with titles taken from old enemies, Pomare even retained most title-holders in their former positions (Davies 196r: 200; Newbury I967b: 499). Pomare's aim was not to do away with the traditional political system, but to place himself at the head of it.

Pomare II died in I82I and was succeeded by his son, then a small child. Upon his death in 1827 Aimata, daughter of Pomare II, ascended the throne as Pomare IV and reigned for the next half-century. These changes in the monarchy had little effect on the political system, except that the chiefs increased in power and independence, partly because his successors lacked the ability of Pomare II to run a strong, centralized government (Gunson 1962: 222, 232; Newbury 1967a: 16).

During the period 1815-1842 the traditional political system was bolstered by law codes which stipulated the amount of tribute or taxation which the commoners were to pay to the chiefs and monarchy (Newbury 1967a: 15). Moreover, the position and power of the chiefs were enhanced by their appointment as judges who were to enforce the laws (Bouge 1952; Gunson 1962: 222).

It is, of course, true that conversion did remove the very important religious sanction from the chiefs and the traditional political system, and our first hypothesis lays much weight on that fact. Instead of the chiefs losing their power on this account, however, history suggests that one religious sanction was simply replaced by another: the chiefs became the deacons and other leading lay members of the new Christian church (Gunson 1962: 213; Newbury 1967a: 15, I967b: 499). Hence Tahitian history from 1815 to 1842 provides no support for the hypothesis that conversion to Christianity undermined the authority of the chiefs and brought about the dissolution of traditional political organization.

On the other hand, events after 1842 make it abundantly clear that the breakdown of Tahitian political organization was a result of French colonial rule. The treaty of 1842 establishing a French protectorate over Tahiti stipulated that internal affairs were to remain in native hands. It soon became clear, however, that French governors in Tahiti intended to be active in local affairs. For example, the Tahitians warred intermittently and unsuccessfully against the French between 1843 and 1846 in the hopes of regaining their independence, and at the end of this period the French governor replaced a number of district chiefs who had opposed the French with men he felt would be more loyal (Newbury 1955).

During the following decades the French introduced a number of changes which drastically undermined the traditional political system. In 1848 the system of tribute paid by commoners to the chiefs was replaced by a stipend paid to the chiefs from the French government, thus severing a tie between chiefs and commoners and making the chiefs dependent upon the French. In the process a class of minor chiefs was entirely eliminated, having lost its former tribute but receiving no stipends. In 1852 an Electoral Law was passed whereby succession by primogeniture to the title of district chief was abolished, and district chiefs were thenceforth elected from among any of the previous chief's relatives by the lesser 
chiefs of the district. Queen Pomare IV opposed such interference by the French in internal affairs, but ineffectually. For example, the Electoral Law of $185^{2}$ was not even presented to her for her signature (Newbury I967a: 17-20; E. Salmon 1964: I00-I01, 106-108, I15-121).

The Tahitian courts were a major outlet for chiefly authority, in that the judges were drawn largely from the chiefly classes. In the I86os the French mounted efforts to expand the jurisdiction of French courts at the expense of Tahitian courts. By 1874 they had been successful enough that in nearly all litigation-including that entirely between Tahitians-"'the intervention of French justice became automatic and its goal was always the same: to eliminate the local laws" (Panoff I966: I26, my translation). It even got to the point where Tahitian courts sent to French courts for verification of hereditary titles and genealogies!

At the time of Queen Pomare's death in 1877 the chiefly titles still remained for the most part in the hands of the old aristocratic families (E. Salmon 1964:173). But the titles and the traditional political system they represented were by now hollow; "the occupied portion of the Society Islands was a French colony in all but name" (Newbury i967a: 17). The fiction of an internally autonomous protectorate was dropped in 1880, when France annexed Tahiti and formally assumed full control. Now the French were free to pursue their policy of assimilation more openly and vigorously, and by 1897 the whole idea of chiefly titles held in ranking families was terminated. At the district level the government was entrusted to a District Council of five members, all of whom were elected by universal suffrage. Real power, however, was concentrated in the hands of the governor rather than in any elected body. As West (196r: 98) says,

The district councils have very little power or initiative in deciding policy within a district, because the whole tendency of administration has been to use them as offical instruments, not so much for the execution of policy as to exercise a loose kind of supervision over very limited aspects of government: they are in fact dependent on the central administration, and represent its views and wishes rather than existing in any representative capacity for the Tahitians in the villages.

Essentially this form of government has persisted in French Polynesia down to the present.

The results of our two experimental tests are in agreement, and therefore the choice between the two hypotheses is clear. The traditional political system of Samoa has been largely retained while that of Tahiti has disappeared, not because of different effects of conversion to Christianity, but rather because Samoa experienced a relatively long period of independence followed by colonial policies of indirect rule, while Tahiti underwent a colonial policy aimed at assimilating the Tahitians to French civilization and French citizenship. While this policy has not succeeded in making real Frenchmen of the Tahitians, it certainly has eradicated much of old Tahitian culture, especially the political system.

\section{CONVERSION RECONSIDERED}

While it was not responsible for the dissolution of the old political system, conversion to Christianity did have a heavy impact on Tahitian so- 
ciety in another way. It was conversion, I shall argue (and I am by no means the first to do so), that enabled Pomare II to establish for the first time in Tahitian history a stable, centralized political regime over the entire island of Tahiti plus a number of the surrounding islands.

Pomare was not the first to try to unify Tahiti. In the late I76os an attempt was made on behalf of Teri'irere, the young chief of the district of Papara. However, a coalition of chiefs rose up against the supporters of Teri'irere and refuted the bid (Adams I90r: 42, 74). Indeed, Pomare himself had made unsuccessful earlier attempts to gain control of all Tahiti. He conquered a good deal of territory in 1807 , but in the next year his opponents forged an alliance strong enough to blunt his ambitions (Davies 1961 : 96-130). In general, the period from about the 1760 s to 1815 was unsettled and bloody. One faction and then another would have expansionist dreams and would wage successful war for a time, only to be subdued by a coalition of enemies. No chief was strong enough to conquer the island, because when his allies felt that he was becoming too powerful they often joined his opponents and helped to thwart his ambitions.

A similar situation prevailed in Samoa. There two rival factions-the Pule and the Tumua-were locked in a bloody struggle for supreme power. This rivalry prevented the development of political centralization in Samoa, because one faction's support of a potential king automatically insured the other faction's bitter opposition. The situation in nineteenth century Samoa was further complicated by the presence of three metropolitan powers (Germany, Great Britain, the United States) who often articulated their own rivalry in the idiom of support for opposing natíve factions (Masterman 1934: 131-193; Davidson 1966: 15).

But a difference between Tahiti and Samoa is this: in Samoa the struggles filled the entire nineteenth century and were quelled only when the islands were taken over by Germany and the United States, whereas in Tahiti the native leader Pomare II was able to unite the society under his rule after 1815. The problem is to account for Pomare's success. There was, of course, the victory at Puna'auia in 1815. But winning that battle could not have been sufficient cause for Pomare's centralization of Tahiti. We have seen that other chiefs, even Pomare himself, had enjoyed military victories before, only to go down later in defeat. What, then, was so special about Pomare's victory in 1815 ?

Tahitians felt impotent in battle without divine support. The sanction of the gods was an essential ingredient in any enterprise, and especially in warfare. For example, much of the political intrigue and warfare at the beginning of the nineteenth century revolved around the question of where the image of the powerful god 'Oro should be housed, and who might have access to it for the purpose of making sacrifices (Davies I96I : xxxvii-xxxviii, 4I-47). Enlistment of 'Oro's support was high on the list of priorities of any chief with political and military aspirations.

The critical feature of Pomare's victory in 1815 was that he defeated not only his human opponents, but the old gods as well. Jehovah's victory over the pagan dieties was obviously total, for they had been able to mount abso- 
lutely no resistence or retribution when, after the battle, Pomare ordered the destruction of their images and their sacred places (marae). Clearly, Jehovah was immeasurably stronger than 'Oro and the other native gods. And equally clearly, Jehovah was Pomare's god, for it was Pomare who decreed after his victory that Christianity was Tahiti's sole religion and who in succeeding years (much to the missionaries' consternation) attempted to place himself at the head of the Tahitian church as well as the Tahitian state (Davies Ig6r: 214).

By discrediting the old gods and identifying Jehovah inseparably with his own regime, Pomare ruled out the possibility of effective divine sanction for any coalition against him. Since such sanction was essential in Tahitian eyes, no organized opposition did arise, and Pomare was therefore successful in establishing central rule. ${ }^{4}$

The missionaries Williams and Threlkeld must have glimpsed these things when they claimed in 1821 that Pomare II had attempted to grasp political power over all the islands in the area under the pretext of Christianizing them (Davies 196r: 233-234). And in 1849 the bitter and disillusioned ex-missionary Orsmond, as recorded in Davies (196r: 350-351), summed up conversion in Tahiti in this way:

The King changed his Gods, but he had no other reason but that of consolidating his Government. After his conquest it is true he went by short stages to shew his authority, receive presents from his newly acquired subjects, drink the abundance of native spirits, and then in their inebriety, cast down their Marae and destroy their Gods, thus by strategem taking away from any future rebellion thro the power of the idols which were always leaders in war. That is Tahiti, a race of gluttons. Slow bellies. Murderous in the extreme.

These assessments probably paint Pomare as more cynical than he actually was (see Newbury 1967b: 498-499), but the important point remains: because of conversion, no successful challenge to Pomare's central authority could be mounted.

Goldman (1970: 20-21, 27, 542) has advanced the idea that there is a dynamic inherent to Polynesian culture whereby the political system tends to become even larger and more diverse, as witness the attempts at political centralization which we have detected in both Tahiti and Samoa. Yet only Tahiti achieved this centralization, under Pomare II, while in Samoa factional dispute among rival claimants for power continued until the islands came under German and American control in 1900. We have argued that conversion to Christianity was largely responsible for centralization in Tahiti; probably conversion did not have the same result in Samoa because religion did not underlie political organization in those islands as it did in Tahiti.

This leads us to a rather startling conclusion, namely that, far from undermining Tahitian political organization, conversion to Christianity in fact facilitated its evolutionary development. According to Newbury (1967a: 23):

In a sense, the introduction of Christianity was the continuation of a dynamic process. 
... The political implications of these religious changes were the transcendence of single lineage chiefs .... and the concept of inter-island government.

That is, conversion enabled Pomare to jolt Tahitian politics out of the vicious circle of chiefly rivalries and to move it to a new plane where the inherent potential of large-scale, centralized government was realized.

Glancing around the Polynesian "laboratory" a final time, we can see a parallel in Hawaii. In I8I9, shortly before the arrival of Christian missionaries, the newly installed king Liholiho (Kamehameha II) and his advisers blatantly defied a number of time-honored religious restrictions. This overthrow of the kapu system essentially ended the traditional Hawaiian religion-a religion which, as in Tahiti, was the keystone of political organization and much of the rest of aboriginal Hawaiian culture (Davenport I969: 7-9). As with the analysis for Tahiti advanced here, these developments in Hawaii have been interpreted as linked to the consolidation of a centralized regime and the movement of Hawaiian political organization to a new level (Davenport I969; Webb I965).

If anyone still thinks that cultures are always perfectly harmonious wholes, these considerations should be disillusioning. By the early nineteenth century both Tahiti and Hawaii seem to have reached the point where traditional religion actually impeded political development. It was only the abolition of the old religion and its replacement with a foreign creed that enabled political evolution to continue.

\section{NOTES}

I. I am grateful to the University of Pittsburgh for an Andrew Mellon Postdoctoral Fellowship, during the tenure of which the final draft of this essay was written.

2. This passage from Keesing indicates a parallel between Tahiti and Hawaii. More will be said about this in the conclusion of this paper.

3. This was due mainly to the chiefs' increasing control over land and their regulation of trade with whites (Crocombe 1964: 68-93).

4. It is instructive to note in this regard that when a party of minor chiefs attempted in 1829 to thwart the increasing power of high chiefs on Rarotonga, the movement was explicitly anti-Christian and associated with a pagan revival (Buzacott I866: 40-47; Beaglehole 1957: 30-37).

\section{BIBLIOGRAPHY}

Adams, A. rgor. Tahiti: The Memoirs of Arii Taimai. Paris.

Beaglehole, E. P. 1948. Government and Administration in Polynesia. Specialized Studies in Polynesian Anthropology, ed. K. Luomala et al. Bulletins of the Bernice P. Bishop Museum r93: 58-74.

1957. Social Change in the South Pacific: Rarotonga and Aitutaki. London.

Bouge, L. J. 1952. Première législation tahitienne: le code de Pomare de r8rg. Journal de la Société des Océanistes 8: 5-26.

Buzacott, A. 1866. Mission Life in the Islands of the Pacific. London.

Crocombe, R. G. 1964. Land Tenure in the Cook Islands. Melbourne.

Davenport, W. 1969. The Hawaiian "Cultural Revolution": Some Political and Economic Considerations. American Anthropologist 71: I-20.

Davidson, J. W. Ig66. Problems of Pacific History. Journal of Pacific History I: 5-2I.

Davies, J. I96r. The History of the Tahitian Mission, I799-1830, ed. C. W. Newbury. Hakluyt Society, ser. 2, Ir6. Cambridge.

Eggan, F. 1954. Social Anthropology and the Method of Controlled Comparison. American Anthropologist 56: 743-760. 
Goldman, I. I970. Ancient Polynesian Society. Chicago.

Gunson, N. 1962. An Account of the Mamaia or Visionary Heresy of Tahiti, 1826-184I. Journal of the Polynesian Society 7I: 209-243.

Hempel, C. G. 1966. Philosophy of Natural Science. Englewood Cliffs, N.J.

Henry, T. 1928. Ancient Tahiti. Bulletins of the Bernice P. Bishop Museum 48: I-65I. Keesing, F. M. I934a. Modern Samoa: Its Government and Changing Life. London. I934b. Samoa: Islands of Conflict. Foreign Policy Reports 28: 294-304.

I937. The Taupo System of Samoa. Oceania 8: I-I4.

Lowe, W. S., and W. T. G. Airey. 1945. New Zealand Dependencies and the Development of Autonomy. Pacific Affairs 18: 252-272.

Mander, L A. 1954. Some Dependent Peoples of the South Pacific. New York.

Masterman, S. I934. The Origins of International Rivalry in Samoa, I845-1884. Stanford.

Mead, M. I928. The Role of the Individual in Samoan Culture. Journal of the Royal Anthropological Institute 58: 48I-495.

1957. Introduction to Polynesia as a Laboratory for the Development of models in the Study of Cultural Evolution. Journal of the Polynesian Society 66: 145.

Newbury, C. W. 1955. Le gouverneur Bruat et les chefferies tahitiennes. Journal de la Société des Océanistes II : 5-13. 1967a. Aspects of Cultural Change in French Polynesia: The Decline of the Ari'i. Journal of the Polynesian Society 76: 7-26.

1967b. Te Hau Pahu Rahi: Pomare II and the Concept of Inter-Island Government in Eastern Polynesia. Journal of the Polynesian Society 76: 477-514.

Panoff, M. Ig66. Un demi-siècle de contorsions jurisdiques: le régime foncier en Polynésie Française de 1842 á I892. Journal of Pacific History I:II5-I28.

Salmon, E. 1964. Alexandre Salmon et sa femme Arii Taimai. Publications de la Société des Océanistes Ir. Paris.

Salmon, T. rgro. On Ari' is in Tahiti. Journal of the Polynesian Society 19: 39-46. Stanner, W. E. H. I953. The South Seas in Transition. Sydney.

Webb, M. C. 1965. The Abolition of the Taboo System in Hawaii. Journal of the Polynesian Society 74: 21-39.

West, F. J. 196r. Political Advancement in the South Pacific. Melbourne.

Williams, J. I837. A Narrative of Missionary Enterprises in the South Sea Islands. London. 